\title{
P WAVE DURATION AND P-R INTERVAL DURING FIRST WEEK OF LIFE*
}

\author{
BY \\ S. ZOE WALSH \\ From the Barnklinik, Karolinska Hospital and Southern Maternity Hospital, Stockholm, Sweden \\ Received April 24, 1962
}

Interpretation of the electrocardiogram in the neonate is complicated by the profound physiological changes occurring after birth, the pattern and normal variation of which are as yet inadequately documented. Serial examination permits analysis of individual differences that at times may prove more informative than group differences.

In this investigation, electrocardiograms were recorded on 68 infants on their first, second, third, and fifth or sixth day of life, and measurements of the $\mathbf{P}$ wave, $\mathrm{P}-\mathrm{R}$ intervals, and $\mathrm{P}-\mathrm{R}$ segment in lead II were analysed. An attempt was made to include as many of the youngest infants as possible, since it was clear that most previous authors had either not examined this group (Maroney and Rantz, 1950; Coleman, 1961) or not measured these intervals (Datey and Bharucha, 1960) or had studied them only on their first day of life (Kessel, 1953) or had grouped them in such a manner that differences encountered immediately after birth were not noted (Ziegler, 1951; Datey and Bharucha, 1960; and Tudbury and Atkinson, 1950).

\section{METHOD}

All electrocardiograms were taken on a 4-channel Mingograph 42 direct writer by the author, with the help of a full-time assistant. A paper speed of $100 \mathrm{~mm}$./sec. was employed throughout to increase the accuracy of measurement of intervals. The smallest unit of measurement was $0.005 \mathrm{sec}$. The machine was standardized to produce a deflection of $1 \mathrm{~cm}$. with the introduction of $1 \mathrm{mV}$ into the circuit. The heart rate was generally measured on strips of $30 \mathrm{~cm}$. length. Measurements were made in lead II for purposes of comparison with most available data. All $\mathbf{P}$ waves and $\mathbf{P}-\mathbf{R}$ intervals in a single strip were measured using a magnifying lens of $5 \times$ and the maximum value was taken. The P-R segment was calculated by subtracting $\mathbf{P}$ duration from the $\mathbf{P}-\mathbf{R}$ interval.

Infants were either asleep or quietly sucking a pacifier at the time of examination. Every effort was made to disturb the infant as little as possible during the examination and many fell asleep. No records were taken when the infants became restless. Maternal anæsthesia at the time of delivery was little or none. All infants were carefully examined and the chest was X-rayed. None showed clinical evidence of heart disease.

\section{RESULTS}

The infants were divided into two groups according to the time after birth of the initial examination, those 1 hour old or less, Group I (38 cases), and those 90 minutes or more, Group II (30 cases). The mean age and weight of the infants in Group I was 40 minutes and $3450 \mathrm{~g}$. (7 lb. $9 \frac{1}{2} \mathrm{oz}$.); and in Group II, 5 hours 54 minutes and $3555 \mathrm{~g}$. ( $7 \mathrm{lb} .11 \frac{1}{2} \mathrm{oz}$.). Forty-two of the 68 infants were female.

Rate. A wide range in heart rate was noted with a slight increase in the mean from the first to

* This study was supported by the Association for Aid to Crippled Children, New York, N.Y. 
the fourth examination (Table I). The values were similar for both groups and were therefore combined in the Table. The ranges and means encountered were greater than those found by Ziegler (1951) and agreed with those published by Michaelsson (1959). There does not seem to be any satisfactory explanation for this rate increase with age, although it has been ascribed to the

TABLE I

Range and Mean Heart Rates in 68 Infants on Their First, Second, Third, and Fifth or Sixth Day of Life. Groups I AND II are Combined, as No Significant Differences Were Present

\begin{tabular}{l|c|c|c|c}
\hline & 1st day & 2nd day & 3rd day & 5th or 6th day \\
\cline { 2 - 3 } $\begin{array}{l}\text { Range of heart } \\
\text { rates }\end{array}$ & $\begin{array}{c}115-200 \\
150\end{array}$ & $\begin{array}{c}120-195 \\
155\end{array}$ & $\begin{array}{c}105-190 \\
152\end{array}$ & $\begin{array}{c}115-210 \\
160 \cdot 5\end{array}$ \\
\hline
\end{tabular}

older infants being wider awake (Datey and Bharucha, 1960). There is little evidence to support this, and such an explanation seems unlikely. In this study, the youngest infants were wide awake and the older ones tended to fall asleep during the examination. Neonatal activity immediately following birth is dependent in large measure on maternal anæsthesia. For this reason, it is of particular interest that a mean rate increase also occurred in this study where little or no maternal anæsthesia or analgesia was given.

$P$ Wave Duration. On initial examination, infants less than 1 hour old had a $\mathrm{P}$ duration of 0.045 to $0.09 \mathrm{sec}$. with a mean of $0.068 \mathrm{sec}$., while infants in Group II had a range of 0.025 to $0.10 \mathrm{sec}$. with a mean of $0.059 \mathrm{sec}$. (Table II). The range of values and means of both groups greatly exceed those recorded by Ziegler (1951), but are similar to those of Michaelsson (1959). Twentythree infants $(60 \%)$ in Group I in contrast to 6 infants $(20 \%)$ in Group II had an interval of $0.07 \mathrm{sec}$. or more. Within 24 hours, only 2 infants in both groups had a P duration in this range (Table III). No relation between $\mathbf{P}$ wave duration and heart rate was found in either group during the first week of life. This is in accord with Ziegler's (1951) findings. No infant at 5 or 6 days of age had a $P$ duration of more than $0.065 \mathrm{sec}$. In both groups the mean $P$ duration decreased with age, but the decrease was much greater in Group I (Fig. 1 and 2). A slight decrease in the mean also occurred in Ziegler's cases, but whether this decrease was significant cannot be stated here. Furthermore, he included all infants over 24 hours to 1 week of age in one group, and did not state how many of the infants were examined serially, which limits comparison with his data.

TABLE II

Range and Mean Values of P Wave Duration, P-R Interval, and P-R Segment on First, Second, Third, and Fifth or Sixth Day of Life. Significant Decrease in Range and Mean Values Occurs With Age, Notably in INFANTS LeSS ThaN 1 Hour OLd ON FirSt EXAMINATION

\begin{tabular}{|c|c|c|c|c|c|c|c|c|}
\hline & & \multirow{2}{*}{$\begin{array}{c}\text { Age } \\
\text { (days) }\end{array}$} & \multicolumn{2}{|c|}{$\mathbf{P}$ duration (sec.) } & \multicolumn{2}{|c|}{ P-R interval (sec.) } & \multicolumn{2}{|c|}{ P-R segment (sec.) } \\
\hline & & & Range & Mean & Range & Mean & Range & Mean \\
\hline Group I (38 infants) & . & $\begin{array}{c}1 \\
2 \\
3 \\
5 \text { or } 6\end{array}$ & $\begin{array}{l}0.045-0.09 \\
0.04-0.075 \\
0.04-0.065 \\
0.04-0.065\end{array}$ & $\begin{array}{l}0.068 \\
0.057 \\
0.053 \\
0.051\end{array}$ & $\begin{array}{l}0.09-0.16 \\
0.085-0.13 \\
0.08-0.13 \\
0.08-0.13\end{array}$ & $\begin{array}{l}0 \cdot 119 \\
0 \cdot 105 \\
0 \cdot 103 \\
0.096\end{array}$ & $\begin{array}{l}0.02-0.09 \\
0.025-0.07 \\
0.03-0.075 \\
0.025-0.07\end{array}$ & $\begin{array}{l}0.050 \\
0.048 \\
0.050 \\
0.048\end{array}$ \\
\hline Group II (30 infants) & $\ldots$ & $\begin{array}{c}1 \\
2 \\
3 \\
5 \text { or } 6\end{array}$ & $\begin{array}{l}0.025-0.10 \\
0.04-0.08 \\
0.035-0.07 \\
0.03-0.065\end{array}$ & $\begin{array}{l}0.059 \\
0.055 \\
0.053 \\
0.049\end{array}$ & $\begin{array}{l}0.085-0.15 \\
0.08-0.135 \\
0.08-0.14 \\
0.07-0.14\end{array}$ & $\begin{array}{l}0 \cdot 107 \\
0 \cdot 101 \\
0 \cdot 102 \\
0 \cdot 099\end{array}$ & $\begin{array}{l}0.025-0.105 \\
0.025-0.07 \\
0.03-0.08 \\
0.03-0.07\end{array}$ & $\begin{array}{l}0.047 \\
0.047 \\
0.049 \\
0.049\end{array}$ \\
\hline
\end{tabular}


TABLE III

Distribution of Infants According to Heart Rate and P Duration on First and Second Day of Life. By END Of First Week, No Infant Had P DURATION Of More Than 0.065 SeC.

\begin{tabular}{|c|c|c|c|c|c|c|c|c|c|c|}
\hline & & & & \multirow[b]{2}{*}{$\begin{array}{l}P \text { duration } \\
\text { (sec.) }\end{array}$} & \multicolumn{3}{|c|}{ Group I (38 infants) } & \multicolumn{3}{|c|}{ Group II (30 infants) } \\
\hline & & & & & $115-140$ & $145-170$ & $175-210$ & $115-140$ & $145-170$ & $175-210$ \\
\hline 1st day & . & . & .. & $\begin{array}{l}0.065 \text { or }< \\
0.07 \text { or }>\end{array}$ & $\begin{array}{l}7 \\
9\end{array}$ & $\begin{array}{r}8 \\
13\end{array}$ & $\begin{array}{l}0 \\
1\end{array}$ & $\begin{array}{l}8 \\
2\end{array}$ & $\begin{array}{r}13 \\
3\end{array}$ & $\begin{array}{l}3 \\
1\end{array}$ \\
\hline 2nd day & . & . & $\ldots$ & $\begin{array}{l}0.065 \text { or }< \\
0.07 \text { or }>\end{array}$ & $\begin{array}{l}9 \\
2\end{array}$ & $\begin{array}{r}24 \\
0\end{array}$ & $\begin{array}{l}3 \\
0\end{array}$ & $\begin{array}{l}5 \\
0\end{array}$ & $\begin{array}{r}19 \\
2\end{array}$ & $\begin{array}{l}4 \\
0\end{array}$ \\
\hline
\end{tabular}

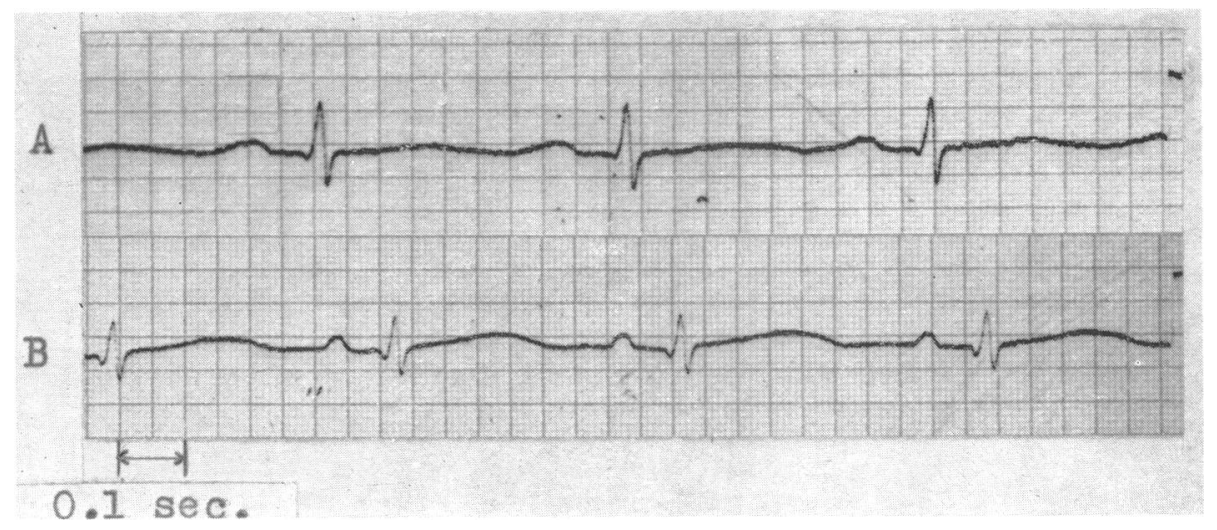

FIG. 1.-Female infant (Group I). Lead II recorded (A) at 50 minutes after birth and (B) at 5 days. The heart rate has increased only very slightly but the $\mathbf{P}$ wave duration and $\mathbf{P}-\mathbf{R}$ interval have both decreased with age.

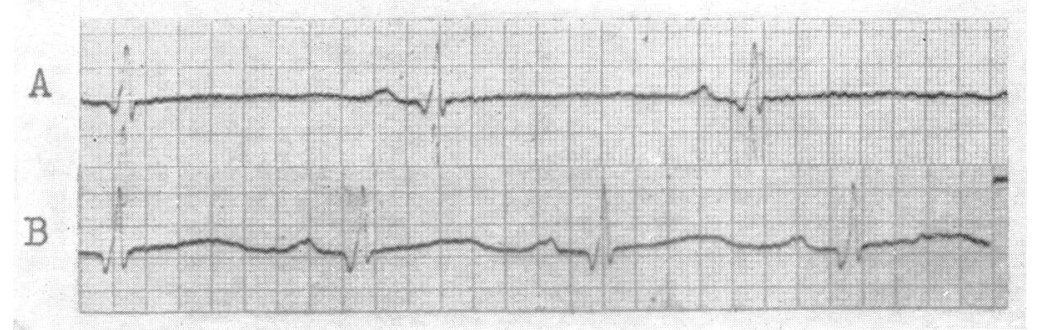

FIG. 2.-Female infant (Group II). Lead II recorded (A) at 8 hours and (B) at 6 days. The heart rate has increased and the $\mathbf{P}$ wave duration and $\mathbf{P}-\mathbf{R}$ interval have remained unchanged.

$P-R$ Interval. On the first day of life the range of the $\mathrm{P}-\mathrm{R}$ interval was similar in both groups, but the mean values were different, $0.119 \mathrm{sec}$. in Group I and $0.107 \mathrm{sec}$. in Group II. Twenty-four infants (63 per cent) in Group I had a P-R interval of 0.115 to $0.16 \mathrm{sec}$. while only 8 infants $(26$ per cent) in Group II had a similar range. Three-quarters of the infants in the latter group had a P-R interval of 0.085 to $0.11 \mathrm{sec}$. By the second day no infant had a $P-R$ interval of more than $0.135 \mathrm{sec}$. and three-quarters of the infants in both groups had an interval of 0.085 to $0.11 \mathrm{sec}$., no significant 
change in the P-R interval having occurred in those in Group II (Table IV). By the end of the first week of life, the mean values had decreased to 0.096 and 0.099 sec. in Groups I and II respectively (Table II). These values exceed Ziegler's (1951), presumably because the infants he studied were older at the time of initial examination.

TABLE IV

Distribution of Infants According to Heart Rate and P-R Interval on First and Second Day of Life. By

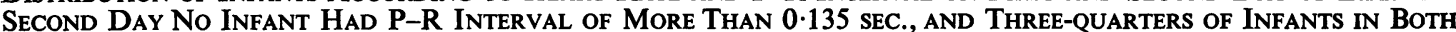
Groups Had INTERVAL OF 0.085-0.11 SEC.

\begin{tabular}{|c|c|c|c|c|c|c|c|c|c|c|}
\hline & & & & \multirow{2}{*}{$\begin{array}{c}\text { P-R } \\
\text { interval } \\
\text { (sec.) }\end{array}$} & \multicolumn{3}{|c|}{$\begin{array}{c}\text { Group I (38 infants) } \\
\text { Heart rate }\end{array}$} & \multicolumn{3}{|c|}{$\begin{array}{l}\text { Group II (30 infants) } \\
\text { Heart rate }\end{array}$} \\
\hline & & & & & $115-140$ & $145-170$ & $175-210$ & $115-140$ & $145-170$ & $175-210$ \\
\hline 1 st day & .. & $\ldots$ & $\ldots$ & $\begin{array}{l}0.085-0 \cdot 11 \\
0 \cdot 115-0 \cdot 135 \\
0 \cdot 14-0 \cdot 16\end{array}$ & $\begin{array}{l}3 \\
9 \\
2\end{array}$ & $\begin{array}{r}10 \\
9 \\
4\end{array}$ & $\begin{array}{l}1 \\
0 \\
0\end{array}$ & $\begin{array}{l}7 \\
3 \\
0\end{array}$ & $\begin{array}{r}11 \\
4 \\
1\end{array}$ & $\begin{array}{l}4 \\
0 \\
0\end{array}$ \\
\hline 2nd day & . & .. & .. & $\begin{array}{l}0.085-0 \cdot 11 \\
0 \cdot 115-0 \cdot 135\end{array}$ & $\begin{array}{l}7 \\
4\end{array}$ & $\begin{array}{r}20 \\
4\end{array}$ & $\begin{array}{l}3 \\
0\end{array}$ & $\begin{array}{l}4 \\
1\end{array}$ & $\begin{array}{r}16 \\
5\end{array}$ & $\begin{array}{l}4 \\
0\end{array}$ \\
\hline
\end{tabular}

Michaelsson (1959) did not encounter P-R intervals of more than $0 \cdot 12$ sec. later than two hours after delivery, but in this study two infants first examined at $4 \frac{1}{2}$ hours and 11 hours had $P-R$ intervals of this length. The same was also found in 10 infants on subsequent examination and in four instances was still present at the end of the first week of life. In only 1 of the 10 infants, however, had the $P-R$ interval not been prolonged on initial examination, and a gradual decrease in the length of the $P-R$ interval was observed.

A correlation between the P-R interval and the heart rate was seen only in infants in Group I at their first examination where a shorter $\mathbf{P}-\mathbf{R}$ interval was found with a faster heart rate. This relation was not present in infants in Group II, nor on later examination during the first week of life in either group. There is some disagreement on the influence of heart rate on the P-R interval. A number of authors (Ziegler, 1951; Tudbury and Atkinson, 1950; Alimurung and Massell, 1956; Hafkesbring, Drawe, and Ashman, 1937) believe that the P-R interval is affected by heart rate, though others doubt this (Furman and Halloran, 1951; and Savilahti, 1946). It is not clear why a disparity exists between the two groups on initial examination, but a decrease in the mean P-R interval occurred with age, especially in infants first examined at the age of one hour or less (Fig. 1 and 2).

Measurements were made to determine whether the decrease in the $P-R$ interval was due to a shortening of the $\mathbf{P}-\mathbf{R}$ segment or of the duration of the $\mathbf{P}$ wave. $\mathbf{P}$ wave duration decreased by 0.01 to $0.045 \mathrm{sec}$. between the first and second examination in 27 infants in Group I and in 10 in Group II. In 7, P wave duration increased, but was associated with a decrease in the P-R segment of the same or greater magnitude in the 3 patients in Group I and in 1 of the 4 patients in Group II. A decrease of 0.01 sec. or more in both $\mathbf{P}$ duration and P-R segment occurred in 9 patients in Group I and in 1 in Group II. It appears, therefore, that shortening of the P-R interval was due primarily to a decrease in $\mathbf{P}$ wave duration although in one-quarter of the cases in Group I a concomitant decrease in the $\mathbf{P}-\mathbf{R}$ segment also occurred.

\section{COMMENT}

The range and mean values of $P$ wave duration and the $P-R$ interval exceed those reported elsewhere for newborn infants. Few serial studies of infants during the first week of life starting within one hour of birth have been performed, and prolongation of these intervals has only once been mentioned (Michaelsson, 1959). The same mechanism may be operative in prolongation of both 
intervals, since it was primarily $\mathbf{P}$ wave duration that was responsible for prolongation of the $\mathbf{P}-\mathbf{R}$ interval. In older subjects the presence of conspicuously widened $P$ waves may indicate left atrial enlargement. Atrial dilatation, however, cannot be differentiated from atrial hypertrophy. It is known that immediately after birth, left atrial pressure rises as a result of increased pulmonary flow. It is possible that temporary prolongation of the $\mathrm{P}$ wave reflects this circulatory change.

On the other hand, transient prolongation of auriculo-ventricular conduction is generally considered to be of vagal origin (Messer, Donegan, and Orgain, 1949), and is attributed to increased potassium permeability of conduction tissue (Lepeschkin, 1959). There is some evidence that vagal tone is active in the neonate, although the question is far from settled. Furthermore, anoxæmia increases the sensitivity of the heart to vagal action, and in the newborn the oxygen saturation may remain low for the first hour of life (Smith, 1959). There are therefore several possible explanations for prolongation of $\mathbf{P}$ and $\mathbf{P}-\mathbf{R}$ intervals during the first hour of life.

\section{SUMMARY}

Electrocardiograms were taken on 68 healthy newborn infants on their first, second, third, and fifth or sixth day of life. P wave duration was not influenced by heart rate at any time during the first week of life. The P-R interval was related to the heart rate in infants only one hour oli or less, but not subsequently. Significant prolongation of $\mathbf{P}$ wave duration and the $\mathbf{P}-\mathbf{R}$ interval was encountered mainly in infants one hour old, or less, and possible mechanisms are discussed.

The technical assistance of Miss Siv Enqvist is gratefully acknowledged.

\section{REFERENCES}

Alimurung, M. M., and Massell, B. F. (1956). Circulation, 13, 257.

Coleman, E. N. (1961). Acta padiat. (Uppsala), 50, 377.

Datey, K. K., and Bharucha, P. E. (1960). Brit. Heart J., 22, 175.

Furman, R. A., and Halloran, W. R. (1951). J. Pediat., 39, 307.

Hafkesbring, E. M., Drawe, C. E., and Ashman, R. (1937). Amer. J. Dis. Child., 53, 1457.

Kessel, I. (1953). Brit. Heart J., 15, 430.

Lepeschkin, E. (1959). Fortschr. Kardiol., 2, 189.

Maroney, M., and Rantz, L. A. (1950). Pediatrics, 5, 396.

Messer, A. L., Donegan, C. K., and Orgain, E. S. (1949). Amer. Heart J., 38, 732.

Michaelsson, M. (1959). Acta padiat. (Uppsala), 48, Suppl. 117, p. 108.

Savilahti, M. (1946). Acta med. scand., 123, 252.

Smith, C. A. (1959). The Physiology of the Newborn Infant. Thomas, Springfield, Illinois.

Tudbury, P. B., and Atkinson, D. W. (1950). J. Pediat., 36, 466.

Ziegler, R. F. (1951). Electrocardiographic Studies in Normal Infants and Children. Thomas, Springfield, Illinois. 